\title{
Statement from the DEGUM board regarding the editorial entitled "Who's Doing Your Scan? A European Perspective on Ultrasound Services."
}

\author{
Stellungnahme des DEGUM-Vorstands zum Editorial „Who's Doing your \\ scan? A European perspective on ultrasound services.”
}

\author{
Correspondence \\ Dr. Kai-Sven Heling \\ Pränataldiagnostik, Friedrichstr. 147, 10117 Berlin, Germany \\ heling@feindiagnostik.de
}

Bibliography

DOI https://doi.org/10.1055/s-0044-100805

Published online: 2018

Ultraschall in Med 2018; 39: 11-13

(c) Georg Thieme Verlag KG, Stuttgart · New York

ISSN 0172-4614
This editorial was published last year in the October issue of EJU (Ultraschall in Med 2017; 38: 479-482), a journal that is read by the members of various European ultrasound societies and especially by the members of DEGUM, ÖGUM and SGUM. In the editorial it states that approx. $80 \%$ of ultrasound services in Great Britain are performed by specially trained sonographers, who provide in addition to the examination also a corresponding report on the examination. Of the remaining examinations, approx. $19 \%$ are performed by the country's radiologists. Only $1 \%$ of examinations are performed by other physicians in private practice, with emergency physicians and fetal medicine specialists being named in this connection. The authors feel that the British system can be classified as a success and could serve as a model for the rest of Europe given the increasing demand for ultrasound examinations. They also mentions that elsewhere in Europe the British system has spawned so far only a few imitators. For that reason alone, a more appropriate title for the editorial would be "A British Perspective..." instead of "A European Perspective...". There is a good reason why this system involving ultrasound services being performed by non-medical personnel is not practiced in many countries. Especially within DEGUM, one of the largest groups within EFSUMB, the delegation of ultrasound services to medical support staff is unpopular. After intensive discussion, a decision was made in 2011 by the extended DEGUM board that clearly states that ultrasound examinations and reporting are to be performed by physicians and cannot be delegated to support staff.

This view is primarily based on the fact that there is a completely different understanding of the importance of ultrasound in Germany than in some other countries, particularly in Anglo-American countries. While ultrasound is viewed in those countries first and foremost as an imaging method, it is accepted in Germany as an additional diagnostic method in the hands of the practising clinician. Ultrasound allows the treating physician to better interprete the personally acquired clinical findings and the physician receives within a very short time a working diagnosis that can be used as the basis for medical decisions. For the patients, this system has the enormous advantage that there are no long wait times for complex additional examinations and that other examinations, possibly involving exposure to radiation, are often unnecessary.

However, this also means that effective and high-quality use of ultrasound in the medical routine is only possible when combined with other medical tasks and activities. DEGUM recognized this fact early on. Therefore, in contrast to the figures cited by the authors from Great Britain, most ultrasound examinations in Germany are performed by the treating physician of the corresponding medical discipline, such as internists, gynecologists, fetal medicine specialists, abdominal surgeons, head and neck surgeons, urologists, neurologists, etc.

In Germany, the value of clinical ultrasound was recognized decades ago so that ultrasound has become part of the regulations for the specialist training in a wide range of medical disciplines.

From DEGUM's standpoint, it is therefore unimaginable for ultrasound examinations to no longer be performed by a physician in the future and for examinations to be delegated to medical support staff simply because there are examinations that are supposedly simple or unpopular (e.g. residual urine determination or the like). Even with intensive training, a sonographer would not be capable of correctly interpreting clinical findings (including endoscopic findings) let alone acquiring them.

The comprehensive use of sonographers as described by the authors would result in a noticeable decline in ultrasound quality which would then lead to a decrease in the acceptance of ultrasound in the medical community. This would consequently lead to a major increase in the use of other diagnostic imaging methods, such as X-ray, CT, and MRI, resulting in unnecessary radiation exposure for patients. Moreover, major cost increases could be expected.

Ultrasound would be reduced to a pure "imaging modality", without consideration of its true clinical value, namely as a realtime imaging tool in the clinician's hands, allowing quick and highly accurate diagnosis. 
DEGUM also cannot accept the argument that delegation of ultrasound services to medical support staff makes sense because the number of requests for ultrasound examinations is constantly increasing. Any increase in demand can be attributed to the continual improvements in ultrasound technology in recent years and the better training of ultrasound operators. As a result of both of these factors, more detailed information can be acquired from ultrasound examinations today and exact diagnoses can be made. The increase in the demand for ultrasound examinations must not lead to questioning of the basic principles of clinical ultrasound and to ultrasound being removed from the spectrum of diagnostic tools available to physicians. This would be a decisive step backward.

Therefore, from DEGUM's standpoint, it would be inadvisable to jeopardize the quality of ultrasound by delegating examinations to medical support staff. We feel that the quality of ultrasound examinations must continue to increase with respect to patient care and this can only be achieved by developing and applying uniform standards. Quality should always go up not down. France provides proof that such concepts can work. For example, high-quality work using defined standards is being performed there in the field of gynecology and obstetrics, which should be an incentive for us to pursue similar concepts.

Even the continual repetition of the view that the introduction of sonographers for the implementation of ultrasound examinations cannot be stopped does not have the effect that the board of DEGUM will join the view of the editorial. In contrast, DEGUM stands for high quality in ultrasound as described above and this level of quality can only be preserved or improved if ultrasound continues to be viewed as a non-delegable service to be performed by physicians.

PD Dr. Kai - Sven Heling, Prof. Dr. Dirk Becker, Prof. Dr. Peter Jecker, Prof. Dr. Peter Kozlowski, Prof. Dr. Andreas Hagendorff, Dr. Siegfried Krishnabakdi, Prof. Dr. Markus Hahn as the DEGUM board

\section{Stellungnahme des DEGUM-Vorstands zum Editorial „Who's Doing your scan? A European perspective on ultrasound services."}

Dieses Editorial erschien im vergangenen Jahr in der Oktoberausgabe der UiM (Ultraschall in Med 2017; 38: 479 - 482), einer Fachzeitschrift, die neben den Mitgliedern verschiedener europäischer Ultraschall-Gesellschaften vor allem von Mitgliedern von DEGUM, ÖGUM und SGUM gelesen wird. In dem Editorial wird aufgezeigt, dass in Großbritannien ca. 80 \% der Ultraschall-Leistungen von speziell geschulten Sonografie-Assistenten erbracht werden, die neben der Untersuchung selbst auch einen entsprechenden Befund zur Untersuchung erstellen. Von den restlichen Untersuchungen entfallen ca. 19\% auf die Radiologen des Landes. Lediglich $1 \%$ der Untersuchungen entfallen auf andere niedergelassene Ärzte, wobei in diesem Zusammenhang u. a. Notärzte und Pränatalmediziner genannt werden. Die Autoren sehen in dem briti- schen Vorgehen ein erfolgreiches System, welches wegen der zunehmenden Nachfrage an Ultraschall-Untersuchungen durchaus Vorbildcharakter für die restlichen europäischen Länder haben könnte.

Gleichzeitig erwähnen die Autoren aber auch, dass das britische System bisher in Europa nur wenig Nachahmer gefunden hat. Allein schon deshalb sollte die Überschrift besser „A British perspective ..." und nicht „A European perspective ...“ lauten. Denn nicht ohne Grund wird dieses System der Erbringung von Ultraschall-Leistungen durch nicht-ärztliches Personal in vielen Ländern nicht praktiziert. Vor allem in der DEGUM, eine der größten Gruppen innerhalb der EFSUMB, findet die Delegation sonografischer Leistungen an medizinisches Hilfspersonal kaum Freunde. Nach intensiver Diskussion wurde bereits im Jahr 2011 ein entsprechender Beschluss im erweiterten Vorstand der DEGUM gefasst, in dem sich die DEGUM ganz klar dazu bekennt, dass die Durchführung von Ultraschall-Untersuchungen und deren Befundung eine reine ärztliche Leistung ist, die nicht an Hilfspersonal delegiert werden kann.

Diese Ansicht basiert in erster Linie darauf, dass wir in Deutschland ein ganz anderes Verständnis über die Sinnhaftigkeit des Ultraschalls haben, als dies in manch anderen Ländern, vor allem im angloamerikanischen Sprachraum, der Fall ist. Während der Ultraschall dort in erster Linie als Bildgebungsverfahren angesehen wird, findet der Ultraschall bei uns Akzeptanz als zusätzliches Diagnostikum in der Hand des klinisch tätigen Arztes. Durch Nutzung des Ultraschalls kann der behandelnde Arzt die von ihm persönlich erhobenen klinischen Befunde besser deuten und er erhält innerhalb kürzester Zeit eine Arbeitsdiagnose, an der er sein ärztliches Handeln ausrichten kann. Für den Patienten hat dieses System den enormen Vorteil, dass keine langen Wartezeiten bis zur Durchführung aufwendiger Zusatzuntersuchungen anfallen und dass andere, möglicherweise durch Strahlung belastende Untersuchungen, oft überflüssig werden.

Das bedeutet aber auch, dass eine effektive und qualitativ hochwertige Nutzung des Ultraschalls in der ärztlichen Routine nur dann möglich ist, wenn dieser mit anderen ärztlichen Aufgaben bzw. Tätigkeiten kombiniert wird. Das hat man in der DEGUM frühzeitig erkannt. Deshalb werden auch, im Gegensatz zu den von den Autoren aus Großbritannien genannten Zahlen, in Deutschland die meisten Untersuchungen von den behandelnden Ärzten der entsprechenden Fachdisziplin, wie beispielsweise Internisten, Gynäkologen, Pränatalmedizinern, Abdominalchirurgen, Kopf-Halschirurgen, Urologen, Neurologen uvm., durchgeführt.

Denn in Deutschland hat man den Wert des klinischen Ultraschalls schon vor Jahrzehnten erkannt, sodass der Ultraschall mittlerweile fester Bestandteil der Weiterbildungsordnung verschiedenster Fachdisziplinen ist.

Aus Sicht der DEGUM ist es somit unvorstellbar, dass die Ultraschall-Untersuchungen in Zukunft nicht mehr durch einen Arzt/ eine Ärztin durchgeführt werden, sondern dass die Untersuchung an medizinisches Hilfspersonal delegiert wird, nur weil es vielleicht vermeintlich einfache oder ungeliebte Untersuchungen gibt (z. B. Restharnbestimmung o. ä.). Auch bei intensiver Schulung wird ein Sonografie-Assistent nicht in der Lage sein, klinische Befunde (dies wären u. a. auch endoskopische Befunde) korrekt einzuordnen, geschweige denn, sie selbst zu erheben. 
Folge des von den Autoren beschriebenen Systems eines flächendeckenden Einsatzes von Sonografie-Assistenten wäre ein spürbarer Qualitätsrückgang im Ultraschall, was wiederum zu einer Abnahme der Akzeptanz des Ultraschalls innerhalb der Ärzteschaft führen würde. Dies führt dann konsequenterweise zu einem sprunghaften Anstieg anderer diagnostischer Bildgebungsmethoden wie Röntgen, CT oder MRT und zu einer unnötigen Strahlenbelastung unserer Patienten. Darüber hinaus wäre eine Kostenexplosion zu erwarten.

Der Ultraschall hingegen würde auf ein reines „Bildgebungsverfahren“ reduziert werden ohne Berücksichtigung seines eigentlichen klinischen Sinnes, nämlich als Real-time- Bildgebungsverfahren in der Hand des Klinikers, um schnell und mit hoher Treffsicherheit korrekte Diagnosen zu stellen.

Auch kann aus Sicht der DEGUM das von den Autoren angeführte Argument nicht akzeptiert werden, dass eine Delegation der Ultraschall-Leistung an medizinisches Hilfspersonal Sinn mache, weil die Zahl der Anforderungen an Ultraschall-Untersuchungen stets ansteige. Eine Zunahme der Anforderungen ist einerseits auf die stets verbesserte Ultraschall-Technik der vergangenen Jahre zurückzuführen. Desweiteren ist aber auch davon auszugehen, dass die steigende Zahl an Untersuchungen auf die zunehmend qualifizierte Ausbildung der Anwender des Ultraschalls zurückzuführen ist. Beides führt nämlich dazu, dass heutzutage detaillierte Informationen aus der Ultraschall-Untersuchung gewonnen werden können und exakte Diagnosen gestellt werden können. Die Zunahme der Anforderungen an UltraschallUntersuchungen darf aber nicht dazu führen, dass im gleichen Atemzug das Fundament des klinischen Ultraschalls in Frage ge- stellt wird und dass der Ultraschall aus dem diagnostischen Spektrum des Arztes herausgenommen wird. Dieses Vorgehen wäre ganz klar als Rückschritt zu werten.

Aus Sicht der DEGUM ist es deshalb falsch, Qualität im Ultraschall durch die Delegation der Untersuchung an medizinisches Hilfspersonal zu reduzieren. Im Gegenteil sind wir der Ansicht, dass die Qualität der Ultraschall-Untersuchung auch in Zukunft weiter im Sinne der zu versorgenden Patienten ansteigen muss, was nur durch die Erarbeitung und Anwendung einheitlicher Standards möglich ist. Qualität muss sich nach oben orientieren und nicht nach unten. Dass solche Konzepte funktionieren können, zeigt das Beispiel Frankreich: Dort wird z. B. im Bereich der Gynäkologie und Geburtshilfe eine qualitativ hochwertige Arbeit mit definierten Standards produziert, was für uns ein Ansporn sein sollte, ähnlichen Konzepten nachzueifern.

Auch die permanente Wiederholung der Ansicht, dass sich die Einführung des Sonografers zur Durchführung sonografischer Untersuchungen nicht mehr aufhalten ließe, kann nicht dazu führen, dass sich der DEGUM-Vorstand der Sicht des Editorials anschließt. Im Gegenteil steht die DEGUM für die oben beschriebene hohe Qualität im Ultraschall, die nur aufrechterhalten bzw. verbessert werden kann, wenn der Ultraschall auch zukünftig als nicht delegierbare ärztliche Leistung erbracht wird.

PD Dr. Kai-Sven Heling, Prof. Dr. Dirk Becker, Prof. Dr. Peter Jecker, Prof. Dr. Peter Kozlowski, Prof. Dr. Andreas Hagendorff, Dr. Siegfried Krishnabakdi, Prof. Dr. Markus Hahn als Vorstand der DEGUM 